\section{President Reagan offers strong prescription for a healthy nation}

\section{Washington}

RockeD by political controversy and medical problems, President Ronald Reagan needed to put on a strong performance in his annual State of the Union message delivered last week to Congress. Most agree he did, but many felt he was strong on style and short on substance.

Reagan spent little time discussing the Iran arms scandal, even though it is still in the headlines nearly every day. Instead, he dwelt on familiar topics: support for the Contras in Nicaragua; support for the Strategic Defense Initiative; and criticism of Congress for the "sorry spectacle" of the budget process. Reagan promised to provide to Congress new plans for restoring US competitiveness, including new science and technology centres and "strong new funding" for basic research.

Documents released by the White House to accompany Reagan's speech provided a few more details about how the president plans to achieve renewed competitiveness. Protection of intellectual property, investment in education and research, legal and regulatory reforms, and reducing the budget deficit are all part of the prescription. The president proposes a "Technology Share" programme between federal agencies and consortia of priviate industry and universities. There will also be a push to the new Federal Technology
Transfer act designed to encourage economic development of ideas hatched at national laboratories.

The president renewed his commitment to the US space station, the hypersonic aerospace plane and a global geoscience programme. He also supports a plant science programme to be funded by the National Science Foundation (NSF) and the Departments of Energy and Agriculture. New technology centres, already established in engineering and biology by NSF, are also part of the formula.

Science education will receive one of the largest increases if the president gets his way. NSF's budget for education increases by 50 per cent in 1988 to $\$ 273$ million. In addition to graduate and postgraduate support, NSF will also be turning its attention to improving undergraduate science instruction. The 1988 NSF budget calls for $\$ 68$ million for undergraduate programmes, up \$38 million from the 1987 appropriation. NSF also announced last week a new initiative in science education for 5- to 18-year-old students. The new programme makes NSF funds available to academic publishers for developing coherent science curricula for all the preuniversity years. Publishers will match the NSF funds - $\$ 6.6$ million in the first round of awards - and put 5 per cent of profits into teacher education.

Joseph Palca

\title{
World Health Organisation plans better AIDS management
}

\section{London}

THE World Health Organisation (WHO) has set this year's budget for combating AIDS (acquired immune deficiency syndrome) at US\$43.7 million and has launched an international study to survey trends in AIDS legislation. By the end of the year, the budget will allow about 32 people, twice as many as now, to work full-time on monitoring the disease.

WHO wants to establish itself as the "worldwide clearing house for reliable information on AIDS". To that end, one of its newest and most important research projects is the global survey examining the trends in AIDS legislation. The results of the study would be expected to be presented to an international forum of public health and legal experts whose brief would be to provide guidelines on the alternative approaches to the notification and reporting of AIDS and human immunodeficiency virus (HIV) infection, the protection of blood supplies and donation of organs.

Most legislation so far is concentrated in North America, Australia and Europe, although the highest incidence of the disease is in Africa. There is growing pressure on WHO from its member states to consider AIDS as a global crisis and to ensure that management to combat the disease is centralized, although each country would be self-reliant in fighting the disease.

France has already taken the initiative in legislation. President François Mitterrand has signed the law that will sweep away the taboos that have prevented the advertising of condoms, considered vital in combating the spread of AIDS. Part of the $£ 20$ million health campaign under way in Britain, both in posters and the 20-million-plus home leaflets being distributed nationally, emphasizes the use of condoms but there are severe restrictions on the public advertising of condoms. The same taboos apply in the United States.

The West German government is fighting off the opponents of its public health campaign, part of a DM20 million programme, where newspaper advertising is being used to call for more extensive use of condoms.
Spanish take French lessons

\section{Barcelona}

INSPIRED by the success of the French student riots, Spanish students have taken to the streets in a similar push for reform in education. Their protests, however, have become increasingly violent.

It was left to the Education and Science Minister José Maria Maravall, to conduct the negotiations with the student representatives in an attempt to allay their fears and reach a compromise on the proposed educational reforms.

There are several differences between the Spanish unrest and that in France. Those protesting in Spain were mainly 14

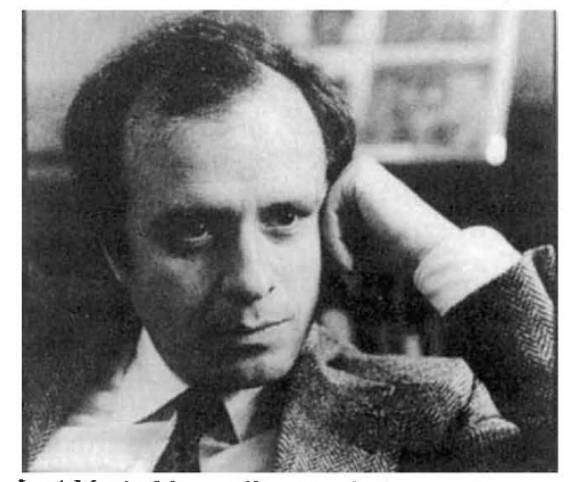

José Maria Maravall - pondering unrest.

to 18 year olds and they opposed two main features of current educational policy introduced over the past three years - the increase in the tuition fees for universities and the introduction of an entrance selection system. Previously, after secondary school, any student could freely enter any faculty in any university.

But the consequences of the "babyboom' in the 1960s created an explosion in the number of university students. Although the number of universities has doubled in the past 20 years, very little attempt has been made to increase the quality of teaching. One solution, popular with university staff but not with students, was to introduce selection. There is now a two-part system in which secondary school results are taken into account with the results of an entrance examination.

Another element in the reform was to allow the universities more autonomy by increasing the tuition fees. After years of relatively modest fees, each student now pays the equivalent each year of half the monthly salary of a middle-class worker.

The new proposals of the Minister of Education and Science to quell the unrest are an increase in the funding for secondary schools; an increase in the number of fellowship and gratuities offered to students from low-income families; freezing of tuition fees; and reform of the university selection procedure.

Pedro Puigdoménech 